\title{
Editorial
}

\section{O MANEJO DE POPULAÇÕES DE ESPÉCIES SILVESTRES}

Em paisagens altamente fragmentadas, invariavelmente, a estrutura das cadeias tróficas é profundamente alterada, com o desaparecimento dos predadores de topo. No Estado de São Paulo, com exceção dos remanescentes de Floresta Ombrófila Densa protegidos em parques e reservas contíguas, pouquíssimas são as áreas com vegetação nativa onde ainda podemos encontrar a onça pintada (Panthera onca Linnaeus, 1758). Dificilmente algum dos mais de 8.000 fragmentos de Cerrado do Estado tem a capacidade de suportar uma população de nosso outro grande felídeo, a Suçuarana (Felis concolor Linnaeus, 1771).

$\mathrm{Na}$ ausência destes predadores, inevitavelmente, as populações de herbívoros como as capivaras (Hydrochoerus hydrochaeris Linnaeus, 1766) crescem rapidamente. A alta disponibilidade de alimentos nas regiões ribeirinhas, quer sejam provenientes de culturas (por exemplo arroz, milho, soja, cana e laranja) quer sejam de pastagens, potencializa a capacidade de reprodução destes animais tornando exponencial o crescimento populacional.

O desequilíbrio pode resultar também no aumento do número de predadores, como é o caso da significativa recuperação das populações do jacaré do pantanal (Caiman crocodilus yacare Daudin, 1802), após o forte declínio induzido pela caça predatória na década de 80. Neste caso ocorreu um sinergismo entre o aperfeiçoamento das técnicas de fiscalização e controle da caça e o desenvolvimento de técnicas de criação do jacaré para produção de carne e peles de origem legal.

A questão que se coloca é como controlar o crescimento exponencial e desordenado de espécies nativas. No caso das capivaras a expansão populacional, além do impacto nas áreas de regeneração da vegetação ciliar, decorrentes do pisoteio e pastoreio excessivo, traz consigo um grave problema de saúde pública, pois a espécie é hospedeira da bactéria Rickettsia rickettsii(Wolbach 1919) Brumpt 1922 que é transmitida ao homem pelo carrapato-estrela (Amblyomma cajennense Fabricius, 1787) e causa a febre maculosa.

O Ponto de Vista deste número da Biota Neotropica traz uma reflexão sobre as alternativas para o manejo da fauna silvestre, incluindo a caça seletiva como forma de controle populacional. O autor destaca que "A complexidade de circunstâncias locais ou regionais impede que um único sistema (caça seletiva ou criação em cativeiro) possa ser pregado como a panacéia de todos os males. A primeira não pode ser aplicada a toda e qualquer população silvestre, pois tem como requisito básico a existência de agregados populacionais e produtividade primária grandes o suficiente para suportar a pressão de caça e tornar economicamente viável a procura e coleta de indivíduos. A criação em cativeiro, por sua vez, por apresentar custo mais alto, só pode ser feita de forma econômica quando se trata de espécies com alto valor unitário"

Este ponto de vista é polêmico. Por diversos motivos muitos defendem que a caça é um desrespeito a vida, não devendo ser utilizada como instrumento de manejo de espécies nativas ou exóticas. Uma alternativa seria estudar a biologia reprodutiva destas espécies e desenvolver métodos e drogas que possam controlar a fertilidade e, consequentemente, a explosão populacional. 
Neste sentido, Programas como o BIOTA/FAPESP, que reunem pesquisadores(as) e projetos que abordam a questão tanto do ponto de vista do diagnóstico e abundância das populações de vertebrados como do ponto de vista da diversidade de modelos reprodutivos, constituem o foro ideal para a discussão de estratégias integradas.

\section{Carlos Alfredo Joly}

Editor da Biota Neotropica 